\title{
Meeting the Challenges of Food Sector using Supplier Relationship Management
}

\author{
M. Raźniewska ${ }^{1}$ \\ ${ }^{1}$ Logistics Department, Faculty of Management, University of Lodz, Poland
}

\begin{abstract}
According to different rapports, one of the most important challenges of nowadays is food security and waste problem. These are also the Sustainable Development Goals till 2030 such as "Zero Hunger", "Responsible Production and Consumption". Strategic and operational interventions can be prioritised across national, regional or industry level in food supply chains. The aim of this article is to present the possibility of using supplier relationship management in securing food and reducing waste. The considerations are based on the following scientific methods: literature analysis, a survey performed using Computer Assisted Telephone Interview among Polish organic distributors. In the article, the role of supplier relationship management in reassuring sustainable business was underlined. As a result, the portfolio of tools and advices for practical use, mostly by purchasing and procurement departments, in food securing and reducing waste was presented. The most important ones are as follows: traceability, measuring performance, evaluations and collaborative actions.
\end{abstract}

Keywords: food security; food waste; relationship management; supply chain; sustainable goals

\section{Introduction}

The challenge of today being supplying healthy diets to 9 billion people in 2050 is very likely to be met thanks to an overall increase in food production (Augustin et al, 2016). All the more the rate at which demand growths is astounding. Until 2050, 2.4 billion people more will be living around the globe. Assuming that per capita incomes and diets have been increasing, in order to sustain global food security, the global food production will need to grow by 70-100\% (FAO, 2009).

Every year about 4.5 trillion tonnes of food is produced worldwide which is paradoxically nearly twice as much as the amount required to satisfy the food needs of the world. Despite this fact, 870 million people in the Earth starve and 2 million (which accounts for $12,5 \%$ of the population) are malnourished (Food and Agriculture Organization of the United Nations, 2013).

Food security and reducing the waste problem, according to different rapports, make up for one of the most important problems of the modern world (EFSA, 2016; RASFF, 2017; FAO, 2017). Its purpose is also to create a sustainable food system which safeguards food and nutrition security in a way (economic, social, and environmental) which does not jeopardise the food and nutrition security of future generations (Bilska et al., 2018; The High Level Panel of Experts, 2014). All people involved in the system of interactions in which one can shape a sustainable consumption have to collaborate actively and interactively in order to teach young people in the spirit of responsible consumption (Popescu et al., 2014). Therefore, sustainable consumption and production are also the Sustainable Development Goals till 2030 such as "Zero Hunger", "Responsible Production and Consumption". It involves reduction of the food waste by half at the retail and consumer levels and food losses at the post-harvest and production stages (United Nations, 2018). Minimalization of food losses throughout the supply chain from production to consumption and sustainable improvements in preservation, nutrient content, safety and shelf life of foods, enabled by food processing is essential (Augustin et al, 2016). Strategic and operational interferences can be prioritised across national, regional or industry level in food supply chains.

Transparency of the supply chain and green supply operation are also important meters among practitioners and scholars in the field of supply management. Companies have been stressed to seriously consider their ecological and ethical values thanks to the increasing awareness of the end-customers in the fields of environment, ecology, and ethics as well as demands to save energy, reduce pollution and 
waste, and ensure consumer safety (Lintukangas et al., 2015). The supplier relationship management could be beneficial.

\section{Challenge of securing food}

Ensuring global food security is still one of the main challenges in the food sector. Different reasons and global trends increase its importance. For instance, the population has been ageing while the demand has been rising. Furthermore, growing income levels alongside increasing food prices, changing demand patterns in the developing the world. The vulnerability of rural farm households has increased due to more frequent and extreme natural disasters caused by climate changes (Grote, 2014). Human development and food security go hand in hand and their results are co-determined to a significant degree. The global food insecurity by 2050 is also strengthened by high competition for resources such as water and land as well as globally urbanised population (Pérez Vázquez et al., 2018). The increasing demand for high quality, value-added and customised agrifood products is dictated by globalisation, along with rapid demographic changes and evolving regulatory and legislative interventions. The food supply chain is an attractive target for terrorist attacks (Lee, 2003). Numerous challenges to equitable food access are concentrated in developing countries where environmental burdens - including climate change, population growth and other socio-economic issues - are concentrated.

In this context, the design, development and operation of efficient agrifood supply chains (AFSCs) have begun to gain the attention of modern management science. Moreover, the plethora of stakeholders involved, the complex food safety regulations, the changing consumers' lifestyle trends, the environmental concerns, the perishability of goods and the instability of weather conditions make for significant challenges towards the development of supply chains within the agrifood sector (Tsolakis, 2014). International megatrends place new demands on regulators, retailers, producers, manufacturers and . This challenge is complicated by a considerable amount of overarching issues, including changing patterns of consumer choice and food consumption, increasing the complexity of food supply chains, an increasingly ageing population and environmental limitations. In this context, food safety must not be an inhibitor but an enabler of global food security (King et al., 2017).

The key problems and challenges in food safety are being laid out by transparency for sustainability in the food supply chain. Both on B2C and B2B market, transparency in the food sector, is one of the contemporary priorities. The increasing need for food policies that ensure that food is safe and of the quality consumers expect comes from various food scandals and deficiencies in consumer communication. Furthermore, consumers increasingly expect that food production processes consider social concerns and limit harmful influences on the environment. Moving toward improved transparency requires not only action by stakeholders of the food chain but also knowledge on how and where to move. Specialists and researchers working in food sourcing, safety, distribution and regulation will benefit from this clear overview (Schiefer and Deiters, 2013). Reaching transparency for different stakeholders from diverse backgrounds and cultural identities is, however, a dynamic process which depends on certain capabilities of organizations and enterprises along the food value chain but also on the realization of a fitting scheme of communication within the area (Fritz and Schiefer, 2010). Supplier relationship management is valuable to work it out.

Some suggestions that could create a culture of healthy and sustainable consumption and nutrition as well as allow facing the future situation of food insecurity are possible.

Firstly, food policy has a unique role for private, non-profit, public and academic stakeholders.

In order to achieve food security by the year 2050 it should be treated as a matter of national security, and because of that it is necessary to be clear about this challenge and to promote technological progress, research processes and innovation on food safety with a true commitment and far-reaching vision (Pérez Vázquez et al., 2018). Policy reforms in agriculture and beyond aid in reducing distortions and changing consumers' awareness with respect to food waste and resource use inefficiencies linked to human diets. What is new in this context is the increasing connection between agriculture with other areas such as the financial and the energy markets (Grote, 2014). 
Increasing the efficiency of the food marketing system and promoting the productivity of farming are effective measures contributing to rural development in developing countries (Grote, 2014).

Digital technologies will lead to the next agricultural revolution, according to some researchers (Walter et al., 2017). It is proposed that eco-intensive high-tech agriculture can lead to overcoming food needs based on sustainable high-tech management (remote sensing, computers, drones and cybernetic management), where conventional agroecological, agricultural, and biotechnological practices could exist alongside each other in a harmonious relationship in order to produce more and better food with less impact on the environment (Pérez Vázquez et al., 2018). Advances in technology and science such as active packaging, whole genome sequencing, developments in tracing and tracking technologies, information computing technology and big data analysis have the potential to help alleviate the challenges and meet demands, but will also contribute to the creation of new challenges. Overcoming many of these challenges will not be easy for developed economies and large food companies, but it will pose an even greater threat for small and medium-sized enterprises (SMEs), developing economies and smallholder farmers, noting that each is a vital component in the global food supply (King et al., 2014).

Climate-smart agriculture (CSA) is a method for altering and reorienting agricultural systems to support food security under the new realities which arose because of climate change. Widespread changes in temperature and rainfall patterns threaten agricultural production and raise the vulnerability of people relying on agriculture for their livelihoods, which includes most of the world's poor. Climate change disrupts food markets, posing a population-wide danger to the food supply. Threats can be reduced by increasing resilience and resource use efficiency in agricultural production systems as well as increasing the adaptive capacity of farmers. CSA advocates for coordinated actions by researchers, policymakers, farmers, the private sector and civil society towards climate-resilient pathways through four key action areas: increasing local institutional effectiveness, building evidence, linking climate and agricultural funding, fostering consistency between climate and agricultural policies. CSA is different from 'business-as-usual' approaches by highlighting the capacity to implement flexible, context-specific solutions, supported by innovative policy and funding actions (Lipper et al., 2014).

Furthermore, urbanisation intensifies the role of establishing urban farms, supported by preferably formal urban agriculture program. It impacts the positive social change implications of urban farms including better food visibility and food access in low-income areas as well as raising consumer awareness about growing fresh food (DiDomenica and Gordon, 2016).

\section{Challenge of reducing waste food}

While trying to specify the extent of a problem, it is only adequate to present only one of the organizations - supermarket. One supermarket has wasted approximately 3.3 tonnes of food over two weeks, according to Bilska et al. with a total value of (sic)5500, mostly meat, fruits and vegetables, cold meals and fish. The estimated caloric value of dairy products wasted during two weeks amounts to approximately $243.8 \mathrm{kcal}$. The estimated mass of dairy products appropriated for social purposes would feed from 72 to 174 persons per day (depending on the daily reference value) (Bilska et al., 2018).

However, worldwide food waste happens at each of the stages in supply chain management, namely within agricultural production, post-harvest handling and storage, processing, distribution and final consumption. Food waste occurs across the supply chain, including all entities - farms, manufacturers, retailers, consumer-facing business like restaurants or catering services as well as individual consumers (Ocicka, Raźniewska, 2018). In order to reach this ambitious goal, effective prevention measures have to be implemented. This requires comprehensive knowledge on drivers and reasons for food waste generation along the food supply chain and the 'hotspots of wastage' (Priefer et al., 2016). Strict private standards are attributed by Davey \& Richards as the main cause of food waste in the fresh food supply chains of industrialised countries (Davey and Richards, 2013). These are as follows (Devin and Richards, 2018):

- strict supermarket specifications,

- requirement about the quality, 
- non-compliance with food safety requirements,

- unsophisticated supply chains,

- marketing standards or logistic constraints, f. ex transportation problems, requirements such as minimum order value,

- handling of food products in the store, exceeding of expiry dates,

- 'price control' (i.e., as one food rescue respondent noted: fruit was being thrown away because [supermarkets] didn't want to lower the price), - excess supply. Consequently, retail operator's specifications have a very negative impact on food waste statistics. But this is also the question of the final costumer responsibility. Hopefully, consumer acknowledgement of suboptimal food has been rising, after and before the purchase. In retail targeted and feasible for and acceptable by the food sector strategies, that are based on consumer insights, had been implemented (Rohm et al., 2017).

The main regulation is Directive 2008/98/EC of the European Parliament and of the Council of 19 November 2008 on waste and cancelling certain Directives sets out the hierarchy of waste, in which the first and the most crucial action is prevention. Further desirable activities include recycling, preparing food for reuse, or another recovery, e.g., energy recovery. The last phase is the disposal of food waste; however, the preceding actions should make this step the last resort. Redistribution of the surplus food to the most disadvantaged population is a sustainable and appropriate option for minimalizing food losses, for ex. by non-profit organizations which operate globally (De Boeck et al., 2017). Undoubtedly, food waste management needs system thinking and responsible participation of all parties, particularly NGOs, public authorities, business operators as well as individuals, based on common goals and collaborative actions (Ocicka and Raźniewska, 2018). The role of supplier relationship management is prominent and could consider all of these stages. Especially that according to the European Waste Directive, the EU plans to obligate its Member States to decrease their food waste by 30\% until 2025.

\section{The Role of Supplier Relationship Management}

As of recently, incorporating sustainability into the buyer-supplier sourcing decisions has achieved a significant amount of attention among enterprises and researchers. Even in the literature the notion Sustainable Supplier Relationship Management (SSRM) can be found. It has become a necessity in companies' sustainability efforts. Corporate image of a firm, in terms of environmental, economic and social behaviour, heavily relies on its supply chain and the sustainability performance of each and every chain link, including suppliers and sub-suppliers (Leppelt et al., 2013). The buyer-supplier relationship positively affected the triple bottom line of sustainability which comprises social, economic and environmental performance measures.

In order to achieve the food sector's ambitious goals, the concrete activities have to be realised. Until now most of the prevention measures implemented in the EU Member States were soft instruments like roundtables, awareness campaigns or networks and information platforms. Besides these soft instruments, the paper advocates for the introduction of more rigorous approaches like the abolishment of subsidies on food, amendments to EU regulations and economics (Priefer et al., 2016). Particularly that food wastage is a cost for suppliers. The observations of the Food and Agriculture Organization of the United Nations (2011) are consistent with respondents from both of growers' associations and food 123 rescue organizations which identified that it was typically cheaper for farmers to discard food in situ, rather than pay transport costs to the retailers distribution centre only to have the product 'rejected at the back door' for not meeting the quality standards (Devin and Richards, 2018).

The portfolio of actions which can be taken by suppliers in this field is quite wide and concerns:

- buying and cultivating raw material

The importance of raw material suppliers selections, incessant control of food quality raw material is prominent. $\square$ production

The goods should be produced with date of use as long as possible, adherence to production principles and norms. In this place, the collaborative forecasting and demand planning plays a crucial role. Supplier 
relationship management should also be focused on using after-production rest to produce another product. The possibility to trace the products in supply chains and the steadiness of production is captivating. Traceability: electronic-based traceability systems (ETsystems) which are considered as a valuable instrument for the assurance of food quality and safety, for guaranteeing value added to products and ultimately, for serving the transparency and sustainability of agri-food chains.

For instance, the theoretical concept and related hypotheses are tested by means of PLS-SEM analysis of data which comes from the dairy supply chain in Greece. 'Perceived Control' and most importantly, the 'perceived costs' over the installation and operation of the ETsystem is the most important aspect with the strongest direct effect influencing the intention to install and operate such a system. This effect is stronger when it comes to dairy farmers than in the case of dairy processors. Stronger for dairy farmers is also the mechanism of identification thus, their need to comply with the expectations of their social/business group. Convenient findings offered for regulators and policymakers interested in the way traceability systems could be successfully integrated within an agri-food sector to guarantee its added value. Limiting the number of voluntariness and the implementation of certain mandatory requirements is one tool to exploit and would be more effective at the processors' level (Pappa et al., 2018).

- storage

Proper storage will protect food against contamination, deterioration and damage. In the light of supply chains and supplier relationship management, it is about maintenance of appropriate conditions of food storage by suppliers (insolation, humidity, temperature etc.), systematically service of the warehouse, raw material inventory management in terms of dates and food quality.

- (re)packaging

It is important to the upkeep of appropriate conditions of (re)packing (temperature, humidity, insolation, etc.), re-packaging, eco-labelling. Rationalisation of the package size especially in the case of products with short sell-by date is often the topic of cooperation with suppliers in search of food security. Therefore, for example, the progress in novel food packaging technologies involves retardation in oxidation, aroma emitters, hindered respiratory process, prevention of moisture infusion, use of $\mathrm{CO} 2$ scavengers/emitters, ripeness indicators, prevention of microbial attack, ethylene scavengers, timetemperature sensors, biosensors and sustained release of antioxidants during storage. The novel food packaging technologies besides the function of containment increase the margin of safety and food quality. Thus, the novel food packaging techniques are aiding in fulfilling the demands throughout the food supply chain by adapting to persons own lifestyle (Majid et al., 2018).

- transporting

It is mostly related to the proper preparing of loading, security of shipment and unloading. Return policies turned out to be a major risk factor for waste at the supplier-retailer interface. According to Eriksson, Ghosh et al., in Sweden, the retailer only pays for bread that is sold and any bread which is unsold is returned to the supplier three days before the best-before date. When it comes to fresh fruit and vegetables only goods of 'inadequate' quality are returned but supermarkets have sole rights of determination on quality, posing a risk of returning them to suppliers by labelling unsold fruit and vegetables as inadequate quality. In the case of milk, suppliers take back unsold products but only for waste management. The tendency found in this study was that bread had the highest waste and the most extensive take-back policy. Vegetables and fresh fruit had medium levels of waste, partly due to unverified rejections, while milk had a very low level of waste combined with an even lower level of rejections. It can be concluded that a food supply chain system where the direct costs of waste management or incentives for waste reduction are detached from the organisation responsible for producing the waste poses a significant risk factor in food waste generation and hence is a potential hotspot for waste-reducing measures (Eriksson et al., 2017).

- selling the products on the B2B market

It is possible to discount goods with a short date of use and make-to-order flows management. Value Stream Mapping (VSM) serves not only as a way to identify and decrease food losses and wastes, but also as a way to establish links with nutrient retention in supply chains (De Steur et al., 2016). Using 
supplier relationship management the amount of food wasted could be controlled and for example food which had not sold to distributors could be sold locally (e.g. on market).

Furthermore, when investigating the buyer-supplier relationships deeper, the literature suggests that appropriate communication and structured information exchange are vital components in establishing a long-term partnership and maintaining such a relationship (Ghadim et al., 2018).

The relationship between buyer and supplier can be analysed in three dimensions of food security and reducing waste possibilities: supplier selection, supplier performance review and supplier development (Kumar and Rahman, 2015).

It is essential for organizations seeking to promote green supply chain management to incorporate the environmental criteria into the conventional supplier selection practices. Challenges related to green supplier selection have been broadly recognised by procurement and supplier management professionals. For an organization, the evaluation and selection of the green supplier is a crucial matter due to several tangible and intangible criteria involved (Govindan et al., 2017). Recommendations are derived for future initiatives which should be inspired by already existing initiatives, particularly considering selecting a cooperation with the suitable partners, competencies involved, timing the start of the initiative accordingly, and aiming to soon achieve a large scale (Aschemann-Witzel et al., 2017). The development and execution of practical decision-making instruments that seek to address these challenges are rapidly evolving (Banaeian et al., 2018). The companies are trying to move towards sustainable production (Ghadim et al., 2018). The suppliers can be encouraged to secure food and to waste less of it by using the indices in their performance review by their clients on the B2B market. Awareness of (and therefore initiatives which reduce) food waste that does not directly affect a firm's profit can be reinforced through multi-stakeholder cooperation (Derqui et al., 2016).

Moreover, international trade and technological change in agriculture have substantially improved food security in recent years. For instance, RFID (Radio-frequency identification) is an emerging technology that can usher vast opportunities in the Agri-food sector. Some of the current applications are animal traceability, access control system, library management, automatic toll collection and counterfeit or theft prevention system. Progressions in sensor technology, communication networks and their integration with RFID technology, are expanding the application domain including intelligent transportation, quality control, real-time monitoring, traceability system, food safety, and online information systems for enduser. Unique features of RFID systems show a number of potential benefits like improvements in efficiency and speed of operations, increased precision of information, minimised labour cost, reduction of inventory losses (Kumari et al., 2015).

New technologies in agriculture, as well as policies, need to place more stress on promoting dietary diversity and reducing environmental externalities. Globalising agri-food systems also include changing supply-chain structures, with a rapid rise of modern retailing, new food safety and food quality standards, and higher levels of vertical integration (Qaim, 2017). Digital technologies with the Internet of Things and Big Data are widely considered promising new tools for both increasing competitiveness and productivity in the agri-food sector and ensuring a more sustainable use of resources. Knowledge and insights coming from ever-increasing volumes and a variety of digital data may aid in improving risk management, optimising farm production processes, predicting market trends and enhancing strategic decision-making capabilities. However, advanced data analytics has also the ruinous power to reshape the whole string of markets within the agriculture value chain. Digitisation may fundamentally alter the relations between technology and farms, input suppliers, processing units, traders, retailers and consumers (Kosior, 2018).

\section{Portfolio of tools and advices referring to supplier relationship management in securing food and reducing waste - the case of organic food distributors in Poland}

The goal of the study was to identify the exploitation by Polish organic distributors different methods connected to secure food and reduce waste. The research method used in this paper is a survey based on the research technique Computer Aided Telephone Interview. The study was conducted on a group of 
120 companies that distributes organic food in Poland and employ more than 10 people. The respondents were selected from personnel responsible for supplier relationship management e.g. sourcing managers. The study was conducted in December 2017.

Based on the results, analysed companies most often introduce periodic assessment of suppliers on the basis of results regarding the timeliness of deliveries and apply contractual clauses regarding cooperation with suppliers. On the foundation of efficiency reports in this respect, they subsequently prepare lists of unreliable suppliers and apply financial penalties to them. In addition to punctuality, more than half of the surveyed enterprises also assess suppliers in terms of quality assurance of deliveries. The results of the survey also show that cooperation with suppliers is increasingly taking place in electronic data exchange systems, which reduces the risk related to communication disruption in the cooperation.

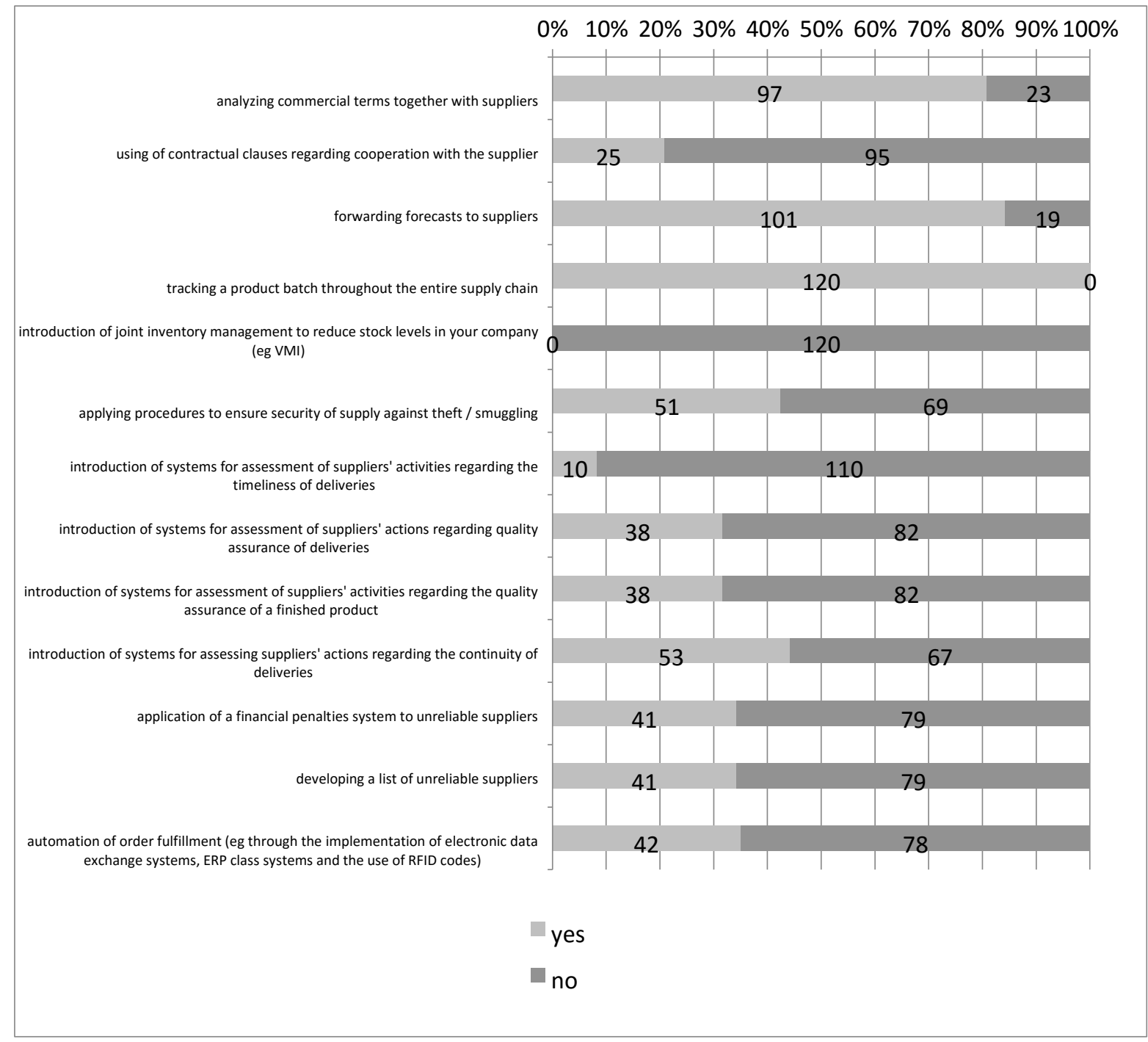

Fig. 1. Activities related to assuring the security using supplier relationships management. Source: own elaboration, $\mathrm{N}=120$.

Besides, the surveyed Polish organic distributors have indicated the following operational recommendation for supplier relationship management:

- more detailed forecasting methods linked to an improved order planning process, using all the expertise available,

- make order amendment more accurate by using correct inventory method, 
- range management including removal of slow moving lines (SKU's) and use tools to assess underperforming lines,

- better design for shelves,

- common reduce packaging,

- insist on measuring waste using tonnes as the common metric (similarly to the retailers to create the possibility of comparing and analysing the data),

- develop 'joint business plans' to drive the supply chain operations with sharing of information and trust.

- closer cross-functional team-working within the organisations and between them,

- improve communications over production planning and order timings, regular touch-points to review progress on a regular basis, regular meetings to evaluate the activities.

\section{Conclusions}

The challenges of food security and waste reduction are important, multi-scalar, cross-sector in nature and complex. It requires the work of diverse actors, including distributors and their suppliers. Each organisation in supply chains can influence and help to reach the ambitious and important sustainable goals. The presented in the article various possibilities and activities could be used in supplier relationship management to reinforce it. Beginning from growing and buying raw material, production, storage, (repacking), transporting to selling products, the importance of suppliers' conscious actions are prominent. Above and beyond, the technology are beneficial in terms of escalating its efficiency. Using tools and advices presented in the article, the supplier relationship management can became a helpful method to fill the obligations referring to the challenges of food sector.

\section{Recommendation and future research}

As a result, the portfolio of tools and advices for practical use, mostly by purchasing and procurement departments, in food securing and reducing waste have been presented. The importance of supplier relationship management and waste management remain the area of author's future research.

\section{References}

1. Aschemann-Witzel, J.; de Hooge, I. E.; Rohm, H.; Normann, A.; Bossle, M. B.; Grønhøj, A.; Oostindjer, M.: In Making, Buying and Collaborating for More Sustainable Production and Consumption, Journal of Cleaner Production, 155, 2, p. 33-45, DOI: 10.1016/j.jclepro.2016.11.173, 2017

2. Augustin, M. A.; Riley, Mal.; Stockmann, R.; et al.: Role of food processing in food and nutrition security, Trends in Food Science \& Technology, vol. 56, p. 115-125, 2016

3. Banaeian, N.; Mobli, H.; Fahimnia, B.; Nielsen, I. E.; Omid, M.: Green supplier selection using fuzzy group decision making methods: A case study from the agri-food industry, Computers \& Operations Research, Vol. 89, p. 337-347, 2018

4. Bilska, B.; Piecek, M.; Kolozyn-Krajewska, D.: A Multifaceted Evaluation of Food Waste in a Polish Supermarket-Case Study, Sustainability, vol. 10, Issue 9, 3175, 2018

5. De Boeck, E.; Jacxsens, L.; Goubert, M.; Uyttendaele, M.: Ensuring food safety in food donations: Case study of the Belgian donation/acceptation chain. Food Res. Int., 100, p. 137-149, 2017

6. Derqui, B.; Fayos, T.; Fernandez, V.: Towards a More Sustainable Food Supply Chain: Opening up Invisible Waste in Food Service, Sustainability, 8, 7, p. 693, http://dx.doi.org/10.3390/su8070693, 2016 


\section{$8^{\text {th }}$ International Conference on Management, Economics and Humanities}

7. De Steur, H.; Wesana, J.; Dora, M.K.; Pearce, D., Gellynck, X.: Applying Value Stream Mapping to reduce food losses and wastes in supply chains: A systematic review, Waste Management -Pergamon Press, 58, p. 359-368, 2016

8. Davey, S.; Richards, C.: Supermarkets and private standards: The unintended consequences of the audit ritual, Agriculture and Human Values, 30(2), p. 271-281, 2013

9. Devin, B.; Richards, C.: Food Waste, Power, and Corporate Social Responsibility in the Australian Food Supply Chain, Journal of Business Ethics, 150, p. 199-210, 2018

10. DiDomenica, B.; Gordon, M.: Journal of Social Change, Vol. 8 Issue 1, p1-13. DOI: 10.5590/JOSC.2016.08.1.01, 2016

11. Directive 2008/98/EC of the European Parliament and of the Council of 19 November 2008 on Waste and Repealing Certain Directives. Official Journal of the European Union L 312/3, 2008. Available online: https://eur-lex.europa.eu/legal-content/EN/TXT/?uri=CELEX\%3A32008L0098 (date of access: 25.10.2018)

12. EFSA, Strategy 2020 Trusted science for safe food Protecting consumers' health with independent scientific advice on the food chain, 2016. Available on the Internet:

http://www.efsa.europa.eu/sites/default/files/corporate_publications/files/strategy2020.pdf (date of access: 14.11.2018)

13. Eriksson, M.; Ghosh, R.; Mattsson, L.; Ismatov, A.: Take-back agreements in the perspective of food waste generation at the supplier-retailer interface, In Resources, Conservation \& Recycling, 122, p. 8393, DOI: 10.1016/j.resconrec.2017.02.006, 2017

14. Food and Agriculture Organization of the United Nations: Food Wastage Footprint: Impacts on Natural Resources; Summary Report, Natural Resources Management and Environment Department, Rome, Italy, 2013. Available on the Internet: http://www.fao.org/docrep/018/i3347e/i3347e.pdf (date of access: 31.10.2018)

15. FAO, Food and Agriculture Organization of the United Nations. Global Agriculture Towards 2050; FAO: Rome, Italy, 2009. Available on the Internet: http://www.fao.org/fileadmin/templates/wsfs/docs/Issues_papers/HLEF2050_Global_Agriculture.pdf (date of access: 31.10.2018)

16. FAO, The State of Food Insecurity and nutrition in the World. FAO, Rome, 2017. Available on the Internet: http://www.fao.org/3/a-I7695e.pdf (date of access: 14.11.2018).

17. Fritz, M.; Schiefer, G.: The Challenge of Reaching Transparency: 'T-readiness' of Enterprises and Sector Networks, International Journal on Food System Dynamics, vol 1, Iss. 3, p. 182-183, 2010

18. Ghadim, P.; Toosi, F.G.; Heavey, C.: A multi-agent systems approach for sustainable supplier selection and order allocation in a partnership supply chain, European Journal of Operational Research, Vol. 269, Issue 1, p. 286-301, 2018

19. Giuseppe, A.; Mario, E.; Cinzia, M.: Economic benefits from food recovery at the retail stage: An application to Italian food chains. Waste Management, 34, p. 1306-1316, 2014

20. Govindan, K.; Kadziński, M.; Sivakumar, R.: Application of a novel PROMETHEE-based method for construction of a group compromise ranking to prioritization of green suppliers in food supply chain, Omega 71, p. 129-145, 2017

21. Grote, U.: Can we improve global food security? A socio-economic and political perspective, Food Security, vol. 6, Issue. 2, p. 187-200, 2014

22. King, T.; Cole, M.; Farber, J. M.; et al.: Food safety for food security: Relationship between global megatrends and developments in food safety, Trends in Food Science \& Technology, vol. 68, p. 160175, 2017

23. Kosior, K.: Digital Transformation in the Agri-Food Sector-Opportunities and Challenge, Roczniki Naukowe Stowarzyszenia Ekonomistów Rolnictwa i Agrobiznesu, 20, 2, p. 98-104, 2018

24. Kumar, D.; Rahman, Z.: Sustainability adoption through buyer supplier relationship across supply chain: A literature review and conceptual framework, International strategic management review, 3(12), p. $110-127,2015$ 
25. Kumari, L.; Narsaiah, K.; Grewal, M. K.; Anurag, R. K.: Review: Application of RFID in agri-food sector, Trends in Food Science \& Technology, 43, p. 144-161. DOI: 10.1016/j.tifs.2015.02.005, 2015

26. Lee, R.; Harbison R,; Draughon F,: Food as a weapon, Food Protection Trends, vol. 23(8), p. 664-674, 2003.

27. Leppelt, T., Foerstl, K., Reuter, C., Hartmann, E.: Sustainability management beyond organizational boundaries-sustainable supplier relationship management in the chemical industry, Journal of Cleaner Production, 56, p. 94-102, DOI:10.1016/j.jclepro.2011.10.011, 2013

28. Lintukangas, K.; Hallikas, J.; Kähkönen, A.; The Role of Green Supply Management in the Development of Sustainable Supply Chain, Corporate Social Responsibility \& Environmental Management, 22(6), p. 321-333, DOI: 10.1002/csr.1348, 2015

29. Lipper, L.; Thornton, P.; Campbell, B. M., et al.: Climate-smart agriculture for food security, Nature Climate Change, Vol. 4, Issue 12, p. 1068-1072, 2014

30. Majid, I.; Ahmad Nayik, G.: Mohammad Dar, S.; Nanda, V.: Review article: Novel food packaging technologies: Innovations and future prospective In Journal of the Saudi Society of Agricultural Sciences, 17(4), p. 454-462, DOI: 10.1016/j.jssas.2016.11.003, 2018

31. Mena, C.; Adenso-Diaz, B. B.; Yurt, O.: The causes of food waste in the supplier-retailer interface: Evidences from the UK and Spain, Resour. Conserv., 55, p. 648-658, 2011

32. Misselhorn, A.; Aggarwal, P.; Ericksen, P.; Gregory, P.; Horn-Phathanothai, L.; Ingram, J.; Wiebe, K.: A vision for attainingfood security, Current Opinion in Environmental Sustainability, Vol. 4(1), p. 717, DOI: 10.1016/j.cosust.2012.01.008, 2012

33. Ocicka, B.; Raźniewska, M.: Food waste reduction as a challenge in supply chains management, LogForum 14 (4), p. 549-561, http://dx.doi.org/10.17270/J.LOG.2018.303, 2018

34. Pappa, I.C., Iliopoulos, C., Massourasm T.: What determines the acceptance and use of electronic traceability systems in agri-food supply chains?, Journal of Rural Studies, 58, p. 123-135, DOI:10.1016/j.jrurstud.2018.01.001, 2018

35. Pérez Vázquez, A.; Leyva Trinidad, D. A.; Gómez Merino, F. C.: Challenges and proposals to achieve food security by the year 2050, Revista Mexicana de Ciencias Agrícolas, 1/1/2018, Vol. 9 Issue 1, p. 175-189, 2018

36. Popescu, C.; Ristea, A. L.; Sticlaru, G.: Challenges of education of young people for responsible food consumption, Risk in Contemporary Economy, vol. 1, Issue 1, p. 387-393, 2014

37. Priefer, C.; Joerissen, J.; Braeutigam, K.-R., , Resources Conservation and Recycling. vol. 109, p. 155165,2016

38. Qaim, M.: Globalisation of agrifood systems and sustainable nutrition, Conference: 12th European Nutrition Conference (FENS) / Conference on Sustainable Food Consumption Location: Berlin, Germany, OCT 20-23, 2015, PROCEEDINGS OF THE NUTRITION SOCIETY, vol. 76, Issue. 1, p. $12-21,2017$

39. Raak, N.; Symmank C.; Zahn, S; Aschemann-Witzel, J., Rohm, H.: Processing-and product-related causes for food waste and implications for the food supply chain, Waste Management, 61, p. 461-472, 2017

40. RASFF, The Rapid Alert System for Food and Feed 2017 Annual Report, European Union, 2018. Available on the Internet:

https://ec.europa.eu/food/sites/food/files/safety/docs/rasff_annual_report_2017.pdf (date of access: 14.11.2018)

41. Rohm. H.; Oostindjer, M.; Aschemann-Witzel, J.; Symmank, C.; Almli, V. L.; de Hooge, I. E.; Normann, A., Karantininis, K., Consumers in a Sustainable Food Supply Chain (COSUS): Understanding Consumer Behavior to Encourage Food Waste Reduction, FOODS, Vol. 6, Issue 12, p. 104,2017

42. Schiefer, G. W.; Deiters, J.: Transparency for Sustainability in the Food Chain : Challenges and Research Needs EFFoST Critical Reviews \#2, London, Academic Press, 2013 
43. The High Level Panel of Experts on Food Security and Nutrition.Food Losess and Waste in the Contex of Sustainable Food Systems. A Report by The High Level Panel of Experts on Food Security and Nutrition of the Committee on World Food Security; HLPE: Rome, Italy, 2014, Available on the Internet: online: https://reliefweb.int/sites/reliefweb.int/files/resources/HLPE-Report-8_EN.pdf (date of access: 31.10 .2018 )

44. Tsolakis, N. K.; Keramydas, C. A.; Toka, A. K.: Agrifood supply chain management: A comprehensive hierarchical decision-making framework and a critical taxonomy, Biosystems Engineering, vol. 120, Special Issue: SI, p. 47-64, 2014

45. United Nations. Sustainable Development Goals. Available on the Internet: https://sustainabledevelopment.un.org/?menu=1300 (date of access: 31.10 .2018 )

46. Walter, A., Finger, R., Huber, R., Buchmann, N.: Opinion: Smart farming is key to developing sustainable agriculture, Proceedings of the National Academy of Sciences of The United States of America, 114 (24): 6148- 6150, 2017. Available on the Internet: http://www.pnas.org/content/114/24/6148.full, (date of access: 31.10.2018)

47. WRAP: Reducing Food Waste through Retail Supply Chain Collaboration, p.18-20, 2011 